\begin{tabular}{|c|c|c|c|}
\hline $\begin{array}{l}\text { Proceedings of the Institution of } \\
\text { Civil Engineers } \\
\text { Engineering Sustainability } 163 \\
\text { June } 2010 \text { Issue ES2 } \\
\text { Pages } 77-87 \\
\text { doi: } 10.1680 / \text { ensu.20 I0.163.2.77 } \\
\text { Paper } 900035 \\
\text { Received 10/07/2009 }\end{array}$ & & & \\
\hline $\begin{array}{l}\text { Accepted } 16 / 1 \text { I/2009 } \\
\text { Keywords: } \\
\text { environment/energy/field testing \& } \\
\text { monitoring }\end{array}$ & $\begin{array}{l}\text { Mark Gillott } \\
\text { Associate Professor, } \\
\text { Co-Director of the } \\
\text { Institute of Sustainable } \\
\text { Energy Technology, } \\
\text { University of } \\
\text { Nottingham, } \\
\text { Nottingham, UK }\end{array}$ & $\begin{array}{l}\text { Lucélia Taranto } \\
\text { Rodrigues } \\
\text { Lecturer, Institute of } \\
\text { Architecture, Faculty of } \\
\text { Engineering, University } \\
\text { of Nottingham, } \\
\text { Nottingham, UK }\end{array}$ & $\begin{array}{l}\text { Catalina Spataru } \\
\text { Research Fellow, } \\
\text { Institute of Sustainable } \\
\text { Energy Technology, } \\
\text { Faculty of Engineering, } \\
\text { University of } \\
\text { Nottingham, } \\
\text { Nottingham, UK }\end{array}$ \\
\hline
\end{tabular}

\title{
Low-carbon housing design informed by research
}

\author{
M. Gillott MSc, PhD, L. Rodrigues DipArch, MSc and C. Spataru MSc, PhD
}

The UK government is committed to cutting greenhouse gas emissions by $\mathbf{8 0} \%$ by $\mathbf{2 0 5 0}$ in a bid to tackle climate change. Dwellings in the UK account for approximately $27 \%$ of the UK total of carbon dioxide emissions through the burning of fossil fuel for heating, lights and appliances. This includes combustion on the premises, mainly natural gas for heating and cooking, and combustion in power stations to produce electricity for homes. In order to address the climate change contribution from the domestic sector, the UK government has stated that every new home needs to be zero-carbon by 2016 . This paper outlines the proposed line of research which will be undertaken on a number of experimental eco-houses constructed at the University of Nottingham. The ongoing work will trial and test different construction solutions and sustainable energy technologies. The paper investigates the role that post-occupancy evaluation will play in ensuring that design aspirations are actually met once the dwellings are inhabited. The work also describes the role that phase change materials and earth air heat exchangers may play as thermal mass substitutes in constructive solutions for housing in a warming climate. These solutions and technologies for ensuring occupant comfort and preventing summer overheating in superinsulated dwellings are likely to become increasingly important as UK temperatures rise owing to man-made climate change.

NOTATION
$C$
$c_{\text {air }}$
CEH
CfSH
EAHE
$\Delta h_{\text {fusion/evaporation }}$
$\Delta h_{\text {latent }}$
ICF
$M$
$m_{\text {air }}$
MMC
PCM
POE
$Q$

specific heat capacity of material $\left(\mathrm{kJ} / \mathrm{kg}^{\circ} \mathrm{C}\right)$ specific heat capacity of air $\left(\mathrm{kJ} / \mathrm{kg} .{ }^{\circ} \mathrm{C}\right)$ creative energy homes code for sustainable homes earth to air heat exchangers the specific latent enthalpy $(\mathrm{kJ} / \mathrm{kg})$ specific latent enthalpy of water $(\mathrm{kJ} / \mathrm{kg})$ insulated concrete formwork mass of material $(\mathrm{kg} / \mathrm{s})$ mass flow rate of air $(\mathrm{kg} / \mathrm{s})$ modern methods of construction phase change materials post-occupancy evaluation quantity of cooling or heating energy delivered $(\mathrm{kW})$

\author{
$Q_{\text {EAHE }}$ \\ SIPs \\ $\Delta T$ \\ quantity of cooling or heating energy \\ delivered by an EAHE (kW) \\ structurally insulated panels \\ temperature difference $\left({ }^{\circ} \mathrm{C}\right)$
}

\section{INTRODUCTION}

Climate change caused by carbon emissions is now accepted as the greatest threat faced by mankind (Brown, 2007), not only in terms of human suffering, but also from the perspective of the global economy (Stern, 2006). The need for action has been recognised, together with the fact that there is a very limited period of time in which to implement changes. In many industrialised countries, more than $40 \%$ of carbon emissions are the result of energy consumption by buildings; within this sector, domestic dwellings are responsible for more than twothirds of the emissions.

In the UK, dwellings account for approximately $27 \%$ of the UK total of carbon dioxide emissions through the burning of fossil fuel for heating, lights and appliances. This includes combustion on the premises, mainly natural gas for heating and cooking, and combustion in power stations to produce electricity for homes. Space heating accounts for 57\%; water heating a further 25\%; cooking 5\% and lights and appliances 13\%.

Contemporary domestic life is now synonymous with the consumption of energy. The average UK household now causes about $6 \mathrm{t}$ of carbon dioxide every year (CLG, 2008).

Furthermore, the demand for energy to run heating/hot water systems and other home appliances such as refrigerators,

cookers, lighting and so on is expected to be 13\% higher in 2010 than it was in 1990. However, the UK government is committed to cutting greenhouse gas emissions by $80 \%$ by 2050 in a bid to tackle climate change.

A reduction in fossil fuel consumption associated with domestic buildings has been addressed in the UK by the government's announcement in 2006 that all new homes will be zero carbon by 2016 with a major progressive tightening of the energy efficiency building regulations (part L) - by 25\% in 2010 and by 44\% in 2013 - up to the zero carbon target in 2016.

In the Budget 2008, it was also announced that all new nondomestic buildings will be zero carbon by 2019 and all new public sector buildings to be zero carbon by 2018. This is in 
addition to the government's earlier commitment that all new schools should be zero carbon from 2016. A zero-carbon home is defined as one where net carbon dioxide emissions resulting from all energy used in the building are zero or better (CLG, 2009). At present this calculation will take account of contributions from on-site renewable/low carbon installations, for example microgeneration technologies such as photovoltaics (PV), micro-wind power and micro-CHP (combined heat and power). If this emissions target is to be achieved, it will be necessary to develop better construction techniques and new low-carbon technologies as well as utilising existing renewable energy technologies for building applications.

Zero-carbon homes will comprise super-insulated envelopes with extremely low levels of heat loss and air infiltration. It is also imperative that we understand how these low or zerocarbon homes perform in reality once occupied so that technologies, systems and building design can respond to occupant behaviour while at the same time remaining 'zero carbon'. The zero-carbon housing challenge will require a greater understanding of building and systems performance. This paper will present work on the implementation of effective post-occupancy evaluation (POE) techniques which will be used to determine whether reality actually meets design aspiration.

In addition to reducing the environmental impact of housing there have also been calls to use fast-track prefabrication techniques to speed up the house building process and reduce wastage and defects. Fast-track construction techniques referred to as modern methods of construction (MMC) in house building have been promoted by the UK government in the last few years as a potential mechanism for reducing the shortage of housing and the consequent increase in house prices.

Most MMC techniques use lightweight materials (e.g. timber or lightweight steel frames) to produce highly insulated buildings with low-infiltration rates through the envelope. The lightweight materials have little thermal mass which naturally provide temperature buffering. This combination of factors can achieve a sharp reduction in the heating loads of a dwelling but is more likely to present overheating, therefore escalating the necessity for air conditioning. It should be noted here that the energy required to cool down the air temperature by $1^{\circ} \mathrm{C}$ is generally much higher than the energy required to warm up the same air.

Air-conditioning use is rising by $8 \%$ annually in the UK, despite the fact that $89 \%$ of occupants prefer buildings without conventional air conditioning (Littlefair, 2005). These issues are particularly important as UK temperatures are set to rise owing to man-made climate change.

The 2005 report by Bill Dunster Architects and Arup R\&D presented research work which illustrated the importance of mitigating climate change effects by designing homes with thermally massive passive features in order to offset the expected temperature increases. The work also stated that thermally lightweight homes would result in substantially higher room temperatures and levels of discomfort (Arup, 2005). Two methods for increasing thermal mass in lightweight buildings will be discussed in the present paper: earth air heat exchangers (EAHE) and phase change materials (PCM).

\section{CREATIVE ENERGY HOMES}

The Creative Energy Homes (CEH) project is a unique research facility located on Green Close at the Department of the Built Environment on the University of Nottingham campus. The project is mainly funded by industry through collaborations between the school of the built environment (SBE) and over 150 project sponsors/partners including main sponsors BASF, Roger Bullivant Ltd, Tarmac, Saint-Gobain and e.on. There will be seven homes in total which will utilise a range of renewable energy and micro-generation technologies including solar thermal systems, ground-source and air-source heat pumps, biomass boilers, solar-photovoltaics, micro-wind and microCHP systems. Two of the houses will be Code for Sustainable Homes (CfSH) level 6 (zero-carbon). The houses are a research and educational showcase of innovative state-of-the-art energy efficient homes of the future. Each home is a 'life-lab', a fully monitored and occupied research test house that will provide researchers with both qualitative and quantitative data on environmental conditions, energy performance characteristics, micro-generation output and occupant behaviour.

The houses will have smart monitor display screens which inform the occupants, researchers and visitors what the homes' environmental and energy performance characteristics are. The homes will include a lightweight steel framed house, a timber constructed dwelling (Passivhaus and CfSH level 6), a home constructed using insulated concrete formwork (ICF) and structurally insulated panels (SIPs) (CfSH level 4), an energy refurbishment project comprising a replica 1930s semi-detached house (brick and breeze-block) which will be refurbished to a 'zero-carbon' standard and a pair of masonry constructed semi detached homes (CfSH levels 4 and 6). Figure 1 illustrates the CEH site.

The work presented here will concentrate on one of the houses that was constructed using MMC techniques. The BASF CfSH level 4 house was completed in January 2008. The ground floor of the house was constructed using ICF (a solution which insulates concrete within two polystyrene boards) and the first floor of the BASF house was constructed using lightweight SIPs building components. It was therefore decided that the home should utilise alternative thermal mass solutions to help regulate internal temperatures.

The use of thermal mass is essential to control internal temperature peaks and fluctuations. A building with thermal storage could shift most of the cooling and heating loads from peak to off-peak periods. In addition, thermal mass coupled with natural ventilation can reduce the peak internal temperature by nearly $5^{\circ} \mathrm{C}$ (CIBSE, 2005). Generally, the term 'thermal mass' is used for any material that is capable of storing heat.

Traditionally, the construction materials used for heat storage in buildings are concrete, adobe, stone and bricks. However, these materials are heavyweight and generally used for on-site construction and assembly, which defeats the benefits of using MMC.

In order to add the desirable thermal mass to the BASF house without adding extra weight, two innovative means were proposed: the exploitation of the ground's mass by the use of EAHE and the addition of latent heat storage by the use of PCM. 


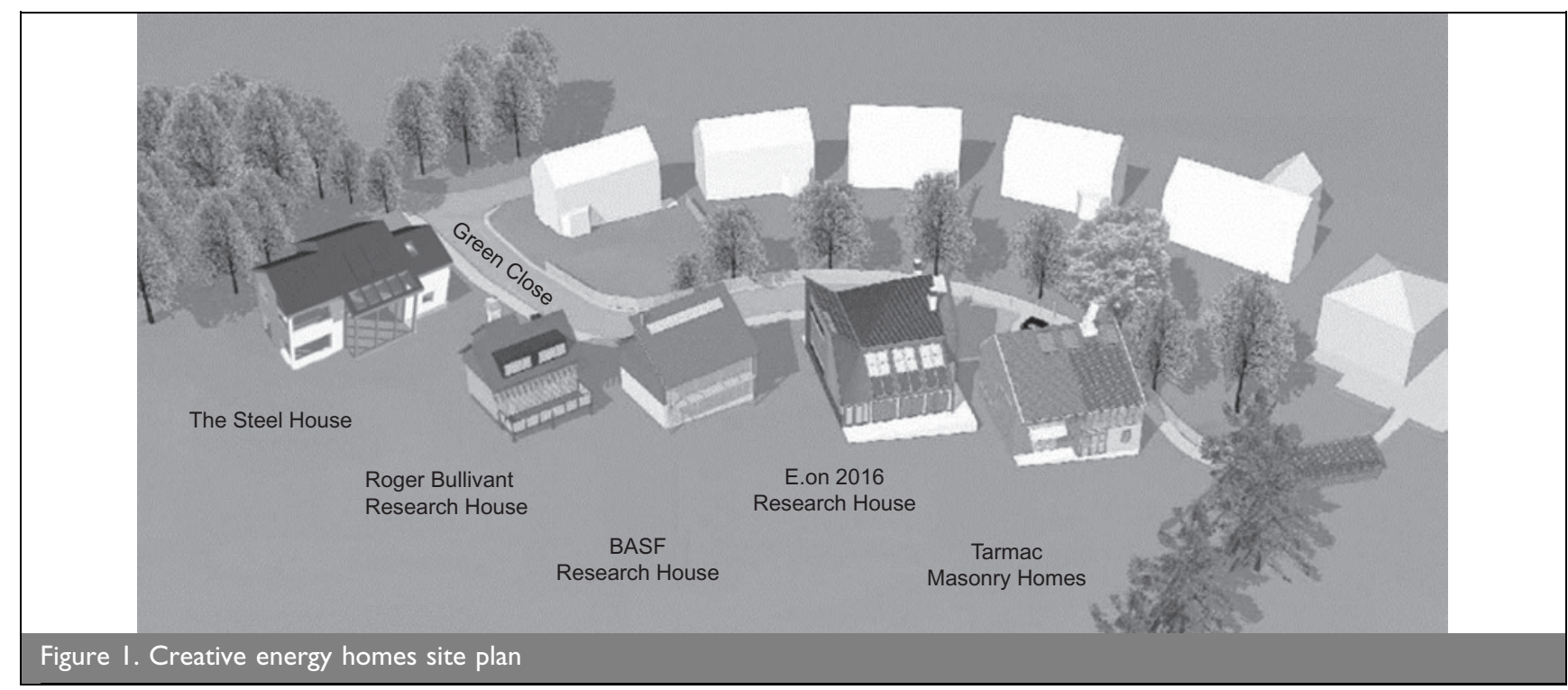

\section{I. Earth to air heat exchangers (EAHEs)}

The idea behind EAHEs is to make use of the mass of earth to dissipate heat by circulating air through buried pipes. These tubes are buried several metres deep where the temperature is approximately constant to avoid the fluctuation on ambient air temperatures. In summer, warm outdoor air entering the tube gives up its heat to the cooler earth, and cools substantially before being delivered to the building. This technique can lower ambient air temperature by $10^{\circ} \mathrm{C}$, possibly even $15^{\circ} \mathrm{C}$, as it is shown in the next section. In winter, the reverse occurs as the soil is likely to be warmer than the outside air which can be preheated up to the earth's temperature before being further heated up by the building's main heating system. Because of pressure losses in the pipe-work, it is common practice for the system to use a fan to blow air through the pipes, although some systems can potentially run by natural means. The pipes need to be buried deep enough to avoid being influenced by ambient temperature swings and be long enough to allow enough exchange of heat. They can be part of a building's foundations or a separate pipe system.

Since these systems can work with little energy, the use of the ground to dissipate excess heat from buildings has received more interest in recent years. Although versions of this technique have been applied over centuries, principally in warmer climates, just over the last decade there has been a renewed interest in EAHEs in Europe. Nonetheless, there is still little knowledge about their application and performance particularly in domestic buildings.

The limited literature available on EAHE installations has shown that some installations have been reported to work effectively. Some examples of effective EAHEs installed in houses are the Coolhouse in Portugal (Fjaerem, 2004; Kennett, 2005), a house designed by Jim Harmon for the harsh desert climate of Imperial Valley in Southern California (Mother Earth News Editors, 1986), the Solar Passive Guest House designed for India (Sawhney, et al., 1997), a house in the South of France (Trombe, et al., 1991), the Monama house in Hyderabad, India (Roaf et al., 2003: p. 304), a two-dwelling building complying with Passivhaus standards in Formerie, north-west of France (Thiers and Peuportier, 2008) and a wooden house in Destelbergen,
Belgium (Meulenaer, et al., 2005), however, few of these works report long-term monitoring of EAHEs. This paper will present one example of two systems installed in houses in the CEH project along with preliminary results. It should be noted that as part of the project's scope, these systems will be monitored over a 20-year period to understand long-term performance and the 4 days of testing covered here should not be regarded as robust long-term performance evaluation.

As suggested above the application of an EAHE to a building may result in significantly lower costs of cooling and heating and consequently a reduction in the carbon dioxide emissions owing to the building's energy usage. Equation 1 can be applied to EAHEs to calculate the potential energy savings using air as the medium. Where there is condensation of water vapour, latent heat is also transferred to the air and may be taken into account.

\begin{tabular}{|c|c|}
\hline I & $Q_{\mathrm{EAHE}}=m_{\text {air }} c_{\text {air }} \Delta T+m \Delta h_{\text {latent }}$ \\
\hline
\end{tabular}

where

$Q_{\text {EAHE }}$ is quantity of cooling or heating energy delivered $(\mathrm{kW})$

$m_{\text {air }}$ is mass flow rate of air $(\mathrm{kg} / \mathrm{s})$

$c_{\text {air }}$ is specific heat capacity of air $\left(\mathrm{kJ} / \mathrm{kg}\right.$. $\left.{ }_{\mathrm{C}}\right)$

$\Delta T$ is temperature difference $\left({ }^{\mathrm{C}}\right)$

$\Delta h_{\text {latent }}$ is specific latent enthalpy of water $(\mathrm{kJ} / \mathrm{kg})$

\subsection{Phase change material (PCM)}

The materials commonly used in construction as thermal mass have the capacity to store sensible heat. As mentioned, these materials are heavy weight and generally constructed on-site. Heat that results in a temperature change is called sensible heat, implying that a temperature change can be sensed. If an object's temperature rises as heat is added or falls as heat is removed then the heat that causes the changes is called sensible. Objects have a heat capacity while materials have a specific heat capacity which is the amount of heat required to change a unit of mass of a substance by one unit of temperature (Bird and Ross, 2002: p. 212, 213). 
Latent heat is the amount of energy in the form of heat released or absorbed by a substance during a change of state. All pure substances are able to change their state for example from solid to liquid or from liquid to gas. In order for the change to happen, energy must be supplied to break the molecular attractions between the constituent particles of a solid substance and allow it to be reorganised. This energy, usually in the form of heat, must be supplied externally and does not cause a change in the substance's temperature and so is called latent heat, meaning a 'hidden' heat (Bird and Ross, 2002: p. 214, 215). Latent heat provides much higher storage capacity at a smaller temperature difference.

The use of PCM in the building's envelope aims to integrate thermal mass in dry assembled lightweight structures without adding unnecessary weight to the construction. PCMs are materials such as salts or paraffin that undergo a phase-change process by reordering their microstructure, which involves the storage and/or release of latent heat. The melting temperature can be adjusted as necessary. If PCM is made to store heat at a useful temperature it will maintain that temperature level until the whole phase change process has taken place, thereby reducing overheating or cooling of the internal air. Therefore, a sort of programmable inertia can be achieved by regulating the melting temperature and the quantity of PCM in the building.

As previously mentioned, traditional building materials used for energy storage utilise sensible heat only. In PCMs, the sensible heat is augmented by the latent heat as defined by the following equation

\begin{tabular}{|l|l|}
\hline 2 & $Q=m c \Delta T+m \Delta h_{\text {fusion/evaporation }}$ \\
\hline
\end{tabular}

where

$Q$ is quantity of cooling or heating energy delivered $(\mathrm{kW})$

$m$ is mass of material $(\mathrm{kg} / \mathrm{s})$

c is specific heat capacity of material $\left(\mathrm{kJ} / \mathrm{kg}^{\circ} \mathrm{C}\right)$

$\Delta T$ is temperature difference $\left({ }^{\circ} \mathrm{C}\right)$

$\Delta h_{\text {fusion/evaporation }}$ is the specific latent enthalpy $(\mathrm{kJ} / \mathrm{kg})$

\section{POST-OCCUPANCY EVALUATION (POE)}

Post-occupancy evaluation (POE) is a key component of the research work undertaken in the $\mathrm{CEH}$ project. All of the houses will be subject to rigorous POE over the coming years. POE is a systematic process of evaluating buildings after they have been built and occupied for some time (Preiser et al., 1988). A POE study consists of physical monitoring (energy usage data and environmental data), experimental data (air leakage test, acoustic performance, co-heating test), field observations (e.g. thermography), assessment of occupant comfort and satisfaction using questionnaires, surveys and interview techniques.

The POE study of the BASF house, and other CEH homes, includes environmental monitoring (using a network of temperature and humidity sensors), electricity (individual power circuits and appliance meters), water use, energy and heat meters for energy associated with space and water heating as well as monitoring

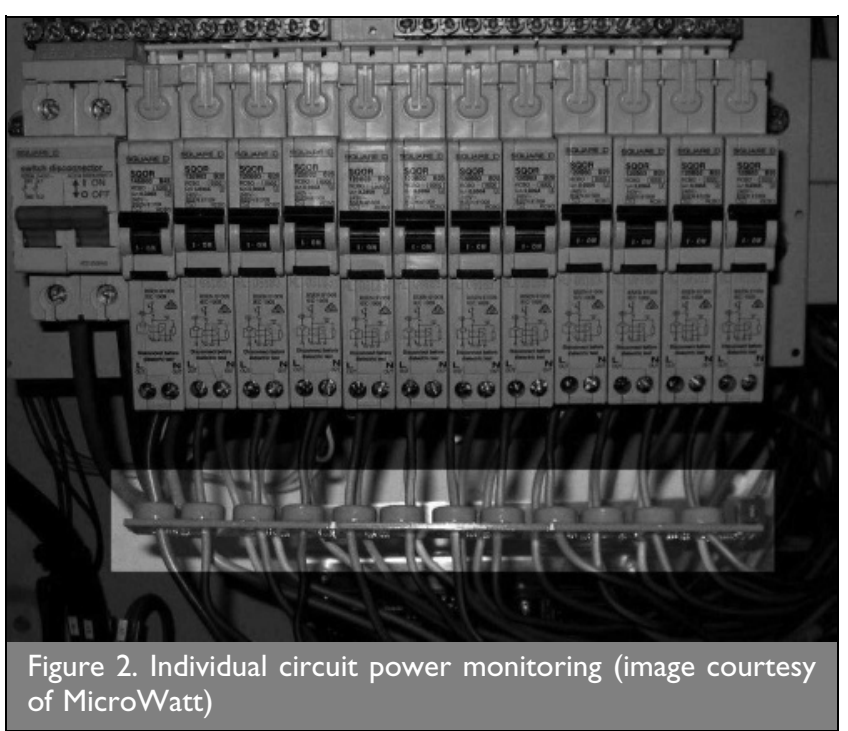

occupancy patterns and space use. Figure 2 shows an example of the type of system that can be installed for monitoring individual power circuits in the distribution board of a house. The current authors have used this system for monitoring power use in a number of buildings. The highlighted area shows current transducers which pick up the current from the magnetic field produced when current flows through the individual circuit cables. The system provides disaggregated power data showing not only how much energy is consumed but where and when it is used. This is extremely valuable information to support decisions such as where and how to make energy savings.

The BASF house is fully instrumented using sensors and monitoring equipment provided by WebBrick Systems. The system oversees and controls the ventilation, heating and lighting for the whole house. Smart monitoring has been installed to measure the use of electricity and water. These data are presented on a touchscreen panel mounted in the kitchen. This same touch screen also provides a user interface with a menu of options for controlling the home. The data collected from the sensors installed in the BASF house are stored locally and can also be accessed by way of the Internet. Figure 3 illustrates an Internet-enabled handheld device and the wall-mounted touch screen, both of which can be used to access data and control systems.

Figure 4 shows a sample of the type of information collected using a typical whole-house monitoring system. The charts clearly illustrate the relationship between energy/water use and the time of day.

For one of the CEH the occupancy patterns and space use are analysed using a real-time and location tracking system (supplied by UBISENSE) which uses ultra wideband radio frequency technology. This is the first time that this technology and system have been used to log occupancy patterns in domestic buildings. The sensors are located strategically in the house so that when the person moves the system is able to detect the worn tag to within an accuracy of $15 \mathrm{~cm}$ in three dimensions. Figure 5 shows a sensor and the tag which the occupants are required to wear during the period of occupancy monitoring.

Providing accurate data on how spaces and buildings are used helps fully to understand the interaction between occupancy 


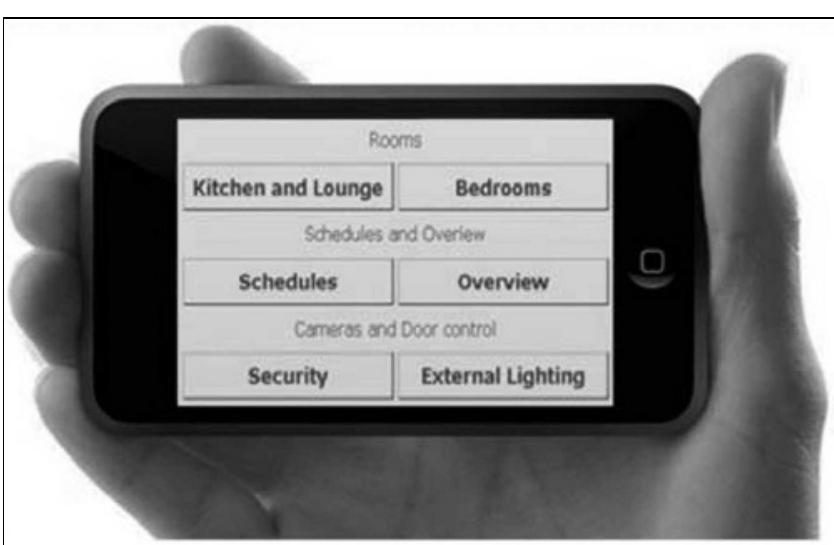

(a)

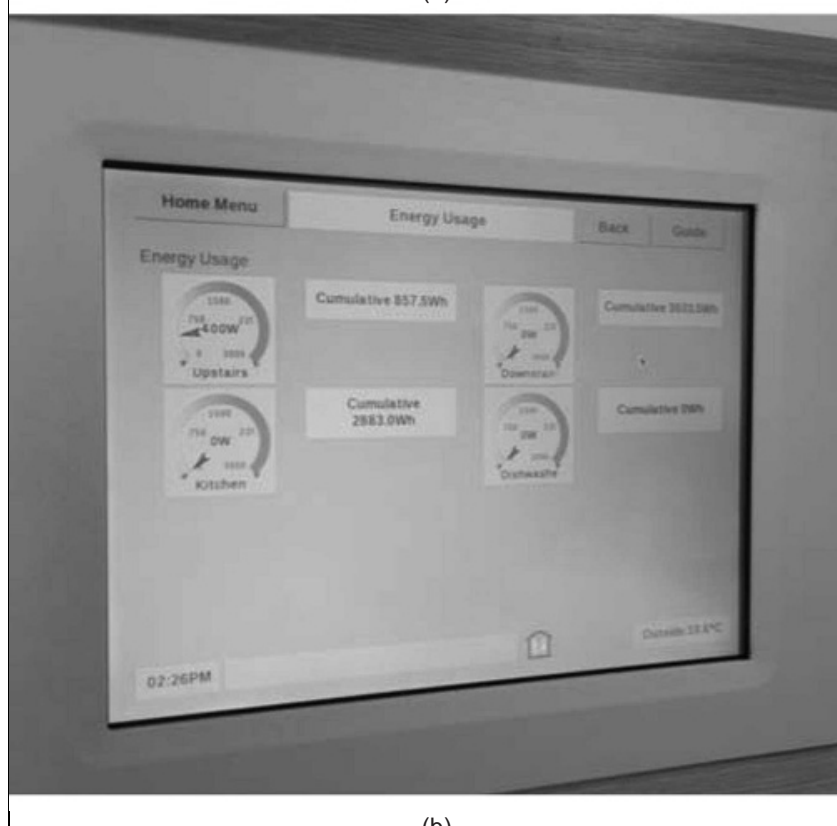

Figure 3. Handheld and wall-mounted smart home controls and whole-house energy monitoring (for the BASF house)

and energy consumption. Furthermore, the data will allow the researchers to correlate individual occupancy patterns with energy use (almost providing individual carbon footprints), as well as to diagnose building performance and energy efficiency.

\section{THE BASF RESEARCH HOUSE}

The BASF house (see Figure 6), designed by Derek Trowell Architects, was completed in January 2008 and thereafter occupied in June 2008 by built environment research students studying at the University of Nottingham. The home has been fully instrumented and monitored since April 2009. The design team also included the SBE and the client and sponsor, BASF. The main targets of the design brief were to minimise (as close as possible to zero) the carbon emissions through energy efficiency and renewable energy systems and to maximise the affordability through cost-effective solutions. These characteristics resulted in a house with a compact floor area and significant reliance on passive solar design.

The house also aimed to achieve Passivhaus standards for energy use: a space heating requirement less than $15 \mathrm{KWh} / \mathrm{m}^{2}$ / annum. However, to account for local climate and construction standards, technical and economic frameworks and different life-styles, the design team proposed an adaptation of the standard to the British context. Owing to the milder UK climate and due to the current UK airtightness standards, a whole-house mechanical ventilation heat recovery system was not specified and so the house is naturally ventilated.

The ground floor includes a 'buffer space' on the north side (shown in Figure 7), which acts as an entrance lobby, houses the control system and is also used as storage for bikes and biomass fuel. This floor has an open plan except for two rooms, the WC and the utility room where the equipment (such as the biomass boiler, solar thermal hot water cylinder and rainwater harvesting control system) are housed. The house is naturally ventilated and the staircase is located in the middle of the plan allowing warm air to flow to the first floor by stack effect and to be extracted by windows placed close to the roof ridge line on the north façade. The first floor has two main south bedrooms, one smaller north bedroom and a family bathroom. There are no windows on the east and west façade so the house can be built as a terrace or semidetached house in future developments. The 'buffer space' on the south side is a double-height sunspace contained within the house's volume and was designed to contribute, through passive solar gains, to the home space heating requirements in the winter months. The space has a number of different opening apertures to ensure that both of the glazed screens to the sunspace can be opened or closed to facilitate heating or cooling. It also has external shading and internal manually-controlled blinds to provide privacy and to prevent summer overheating.

The materials chosen for the building were polystyrene formwork (ICF) filled with concrete for the ground floor walls and for the first floor level, a prefabricated timber insulated sandwich panel (SIPS). These materials were chosen due to practicality, high performance and the ability to be prefabricated off-site speeding up the construction. Although ICFs can be classified as a heavy weight material, they do not potentially offer significant thermal mass as the concrete is sandwiched between polystyrene insulating panels. To overcome this, micro-encapsulated wax PCM contained in wallboards ( $3 \mathrm{~kg}$ of PCM per $\mathrm{m}^{2}$ ) with a phase change temperature of $23^{\circ} \mathrm{C}$ produced by BASF (BASF Knauf Micronal PCM Smartboard) was incorporated in the ceilings of the south-facing rooms of the house. The manufacturer quotes that a Micronal PCM SmartBoard only $1.5 \mathrm{~cm}$ thick has a thermal storage capacity identical with that of $9 \mathrm{~cm}$ concrete or $12 \mathrm{~cm}$ brickwork (BASF, 2008). The different systems used in the construction achieve typical U-values of $0.15 \mathrm{~W} / \mathrm{m}^{2} \mathrm{~K}$ for floor, walls and roof. All the windows are double glazed with a Uvalue of $1.6 \mathrm{~W} / \mathrm{m}^{2} \mathrm{~K}$ except for the external window of the buffer space in the south side which has a U-value of $2 \cdot 7 \mathrm{~W} / \mathrm{m}^{2} \mathrm{~K}$.

The BASF house is thermally efficient, using its passive house design to provide most of its space heating, an aspect that will be monitored and evaluated over the coming years. Nevertheless a biomass boiler was also installed to ensure the comfort of the occupants on extremely cold days. The boiler manufacturer's stated efficiency is $87 \%$. The boiler runs on the waste meal of rape seed. It delivers hot air to a trench heater in the living room perimeter, which is expected to warm up the whole house. A solar thermal system will provide a significant proportion of the annual hot water requirement using a compact solar thermal DWH system. The biomass system also acts as the primary hot water heating system on winter days. One more feature of the house is the Rehau EAHE. The EAHE in the BASF house should provide cool air in summer and pre-heated air in winter. 

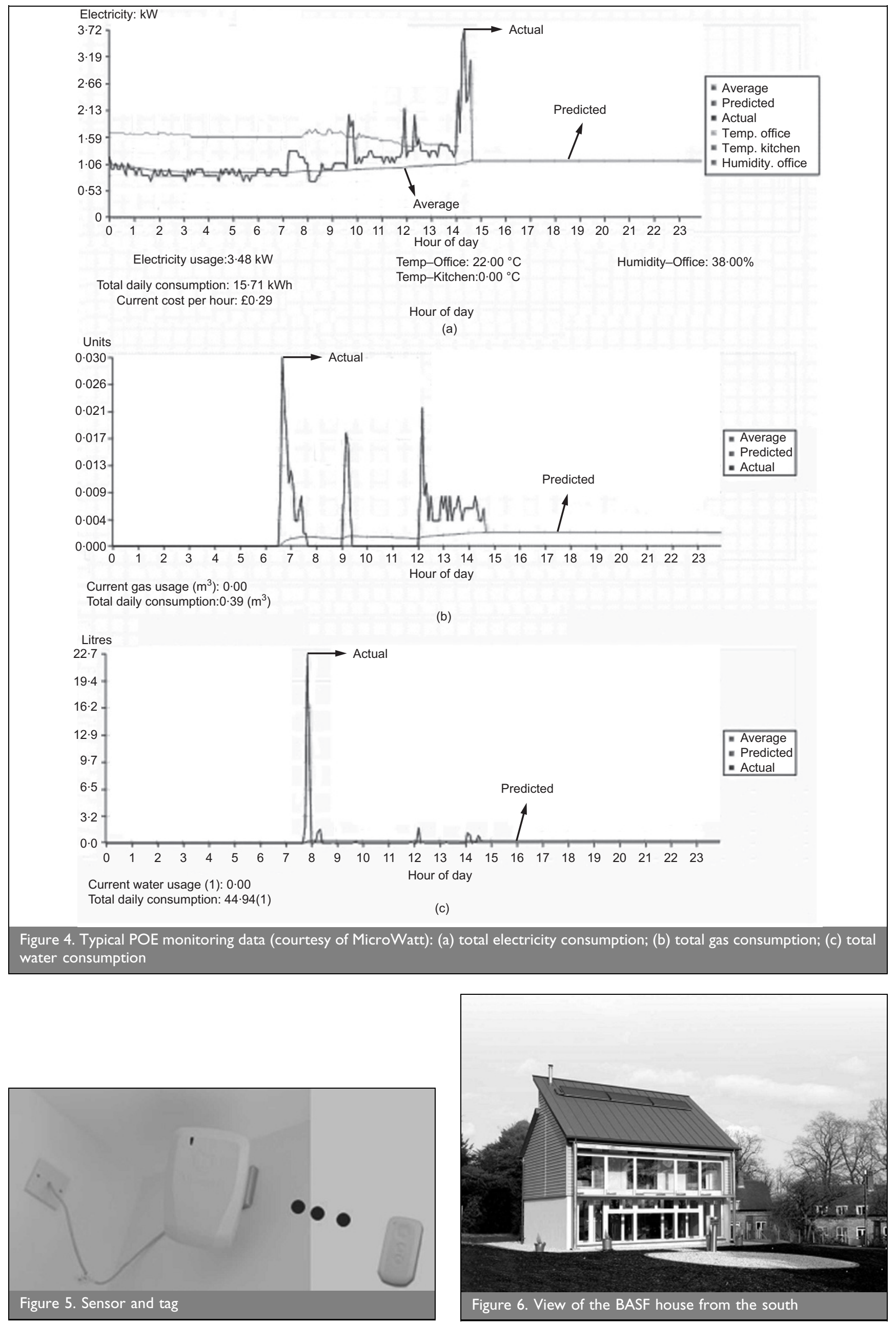


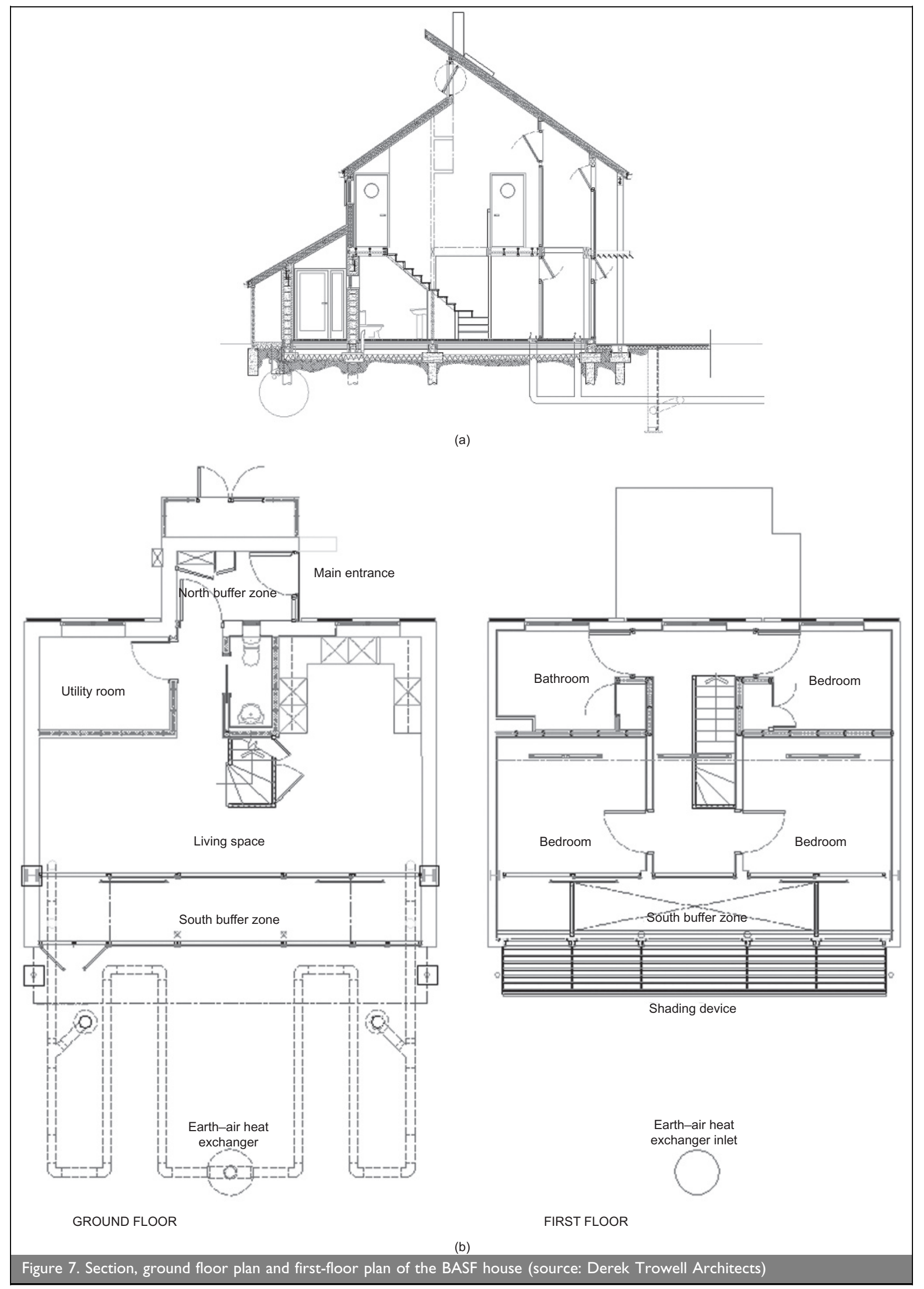


Using ICF and SIPS instead of traditional bricks and blocks significantly reduced the amount of waste generated on-site. The material choice also allowed the whole house to be built in 25 weeks to a very high quality standard. During the design stage and construction of the house significant attention was given to the mitigation of thermal bridging and to reducing air permeability. Owing to the house's simple geometry and due to the high consideration given to design detailing, susceptible areas were well sealed. An on-site pressurisation test was undertaken to determine the actual performance value which was shown to be $3 \cdot 38 \mathrm{~m}^{3} / \mathrm{h} / \mathrm{m}^{2}$ at $50 \mathrm{~Pa}$ pressure difference (the design target was $4 \mathrm{~m}^{3} / \mathrm{h} / \mathrm{m}^{2}$ at $50 \mathrm{~Pa}$ pressure difference). The design's passive approach which included no renewable energy power generation meant that, according to BASF, for a typical 20-home development, the BASF house could be built for just over $£ 70000$. This provides designers and house builders with a realistic airtight, thermally efficient building at an affordable build cost.

Prior to construction, the thermal performance of the design was dynamically simulated using the computer thermal simulation modelling tool TAS by EDSL. The outcome of the simulations informed changes in the design so that the predicted annual heating energy demand for the BASF house is just under the Passivhaus standard of $15 \mathrm{kWh} / \mathrm{m}^{2}$. Active cooling is not required due to the provision of passive mitigations strategies.

\section{PRELIMINARY RESULTS OF THE BASF HOUSE EAHE SYSTEM}

The EAHE system used in the BASF house was a commercially available system called Awadukt Thermo produced by Rehau. The system has filters in the inlet and an antimicrobial pipe inner layer containing the precious metal silver in the pipes to avoid potential problems with air quality. Silver has antimicrobial properties and hence prevents microbe growth which may lead to unpleasant smells. The pipes are made of a PP (polypropylene) material with improved heat conductivity to enhance heat transfer. Any condensation is pumped to a soakaway. The total length is around $36 \mathrm{~m}$ and it is buried at a depth of $1.5 \mathrm{~m}$. The pipe layout is shown in Figures 8 and 9.

The EAHE system was simulated using the company's software Rehau Awadukt Thermo UK using the following parameters

(a) soil type: standard
(i) density: $1800 \mathrm{~kg} / \mathrm{m}^{3}$
(ii) thermal conductivity: $1 \cdot 45 \mathrm{~W} / \mathrm{mK}$
(iii) temperature conductivity: $6 \cdot 015 \times 10^{-7} \mathrm{~m}^{2} / \mathrm{s}$

(b) air flow rate: $174 \mathrm{~m}^{3} / \mathrm{h}$

(c) depth of ground water level: $30 \mathrm{~m}$

(d) fan efficiency: 60\%.

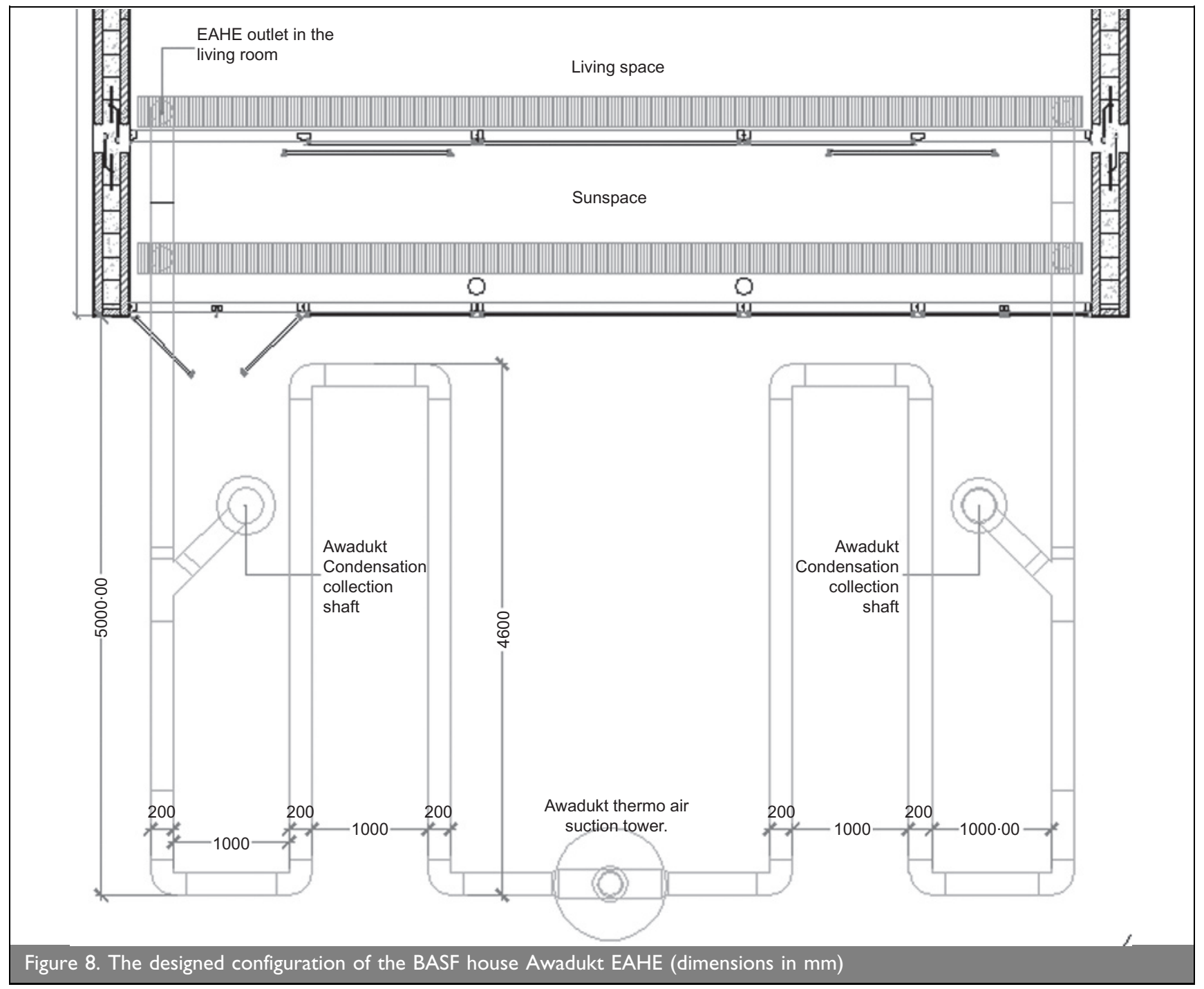




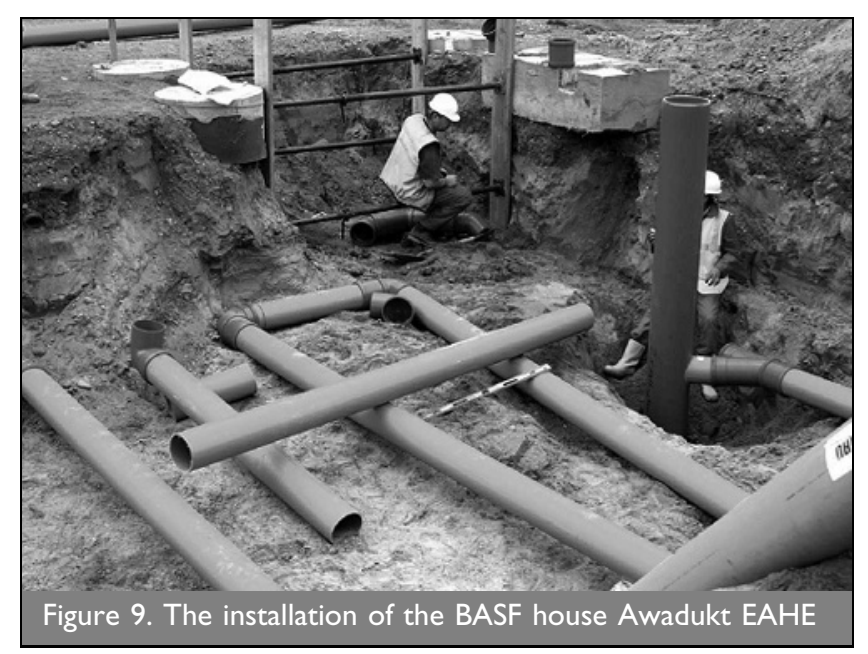

The predicted performance for summer and winter can be seen in Figure 10 and Figure 11.

The resultant air velocity is $1.8 \mathrm{~m} / \mathrm{s}$ and the pressure drop in the pipes is $17 \cdot 3 \mathrm{~Pa}$. The results for winter show a minimum outlet temperature of $1.1^{\circ} \mathrm{C}$, when the ambient air temperature is below $-10 \cdot 0^{\circ} \mathrm{C}$, and a net heat gain of $519 \cdot 7 \mathrm{kWh} / \mathrm{a}$. In summer when the ambient air temperature is just above $30.0^{\circ} \mathrm{C}$ the maximum outlet temperature is $20 \cdot 0^{\circ} \mathrm{C}$ and the net cooling is $247 \cdot 5 \mathrm{kWh} / \mathrm{a}$.

The post-occupancy results discussed here are for monitoring of the system during 4 spring days in 2009: 29 and 30 May and 4 and 5 June. This allowed for some degree of soil saturation to be accessed as well as temperature performance. It should be noted that the occupants chose only to use the system on rare occasions as they felt comfortable without it running. Therefore, the 4-day test was undertaken purely to obtain some measured data and should not be regarded as indicative of long-term performance. Note also that humidity measurements could not be taken at this stage.

The results collected over the spring days can be seen in

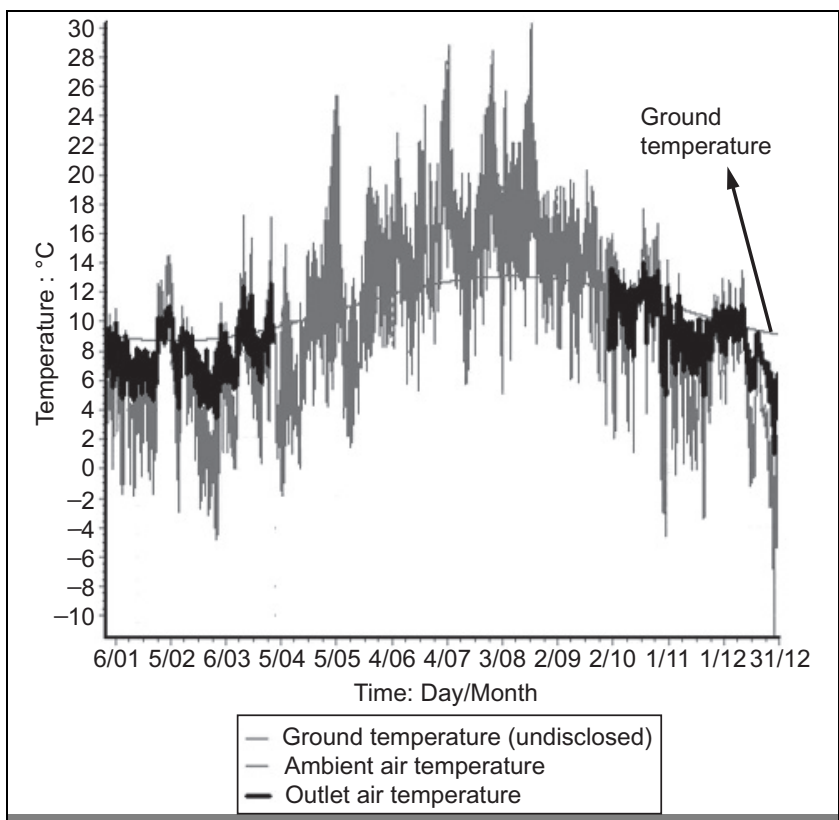

Figure 10. Temperature curves showing winter expected operation of the BASF house Awadukt system

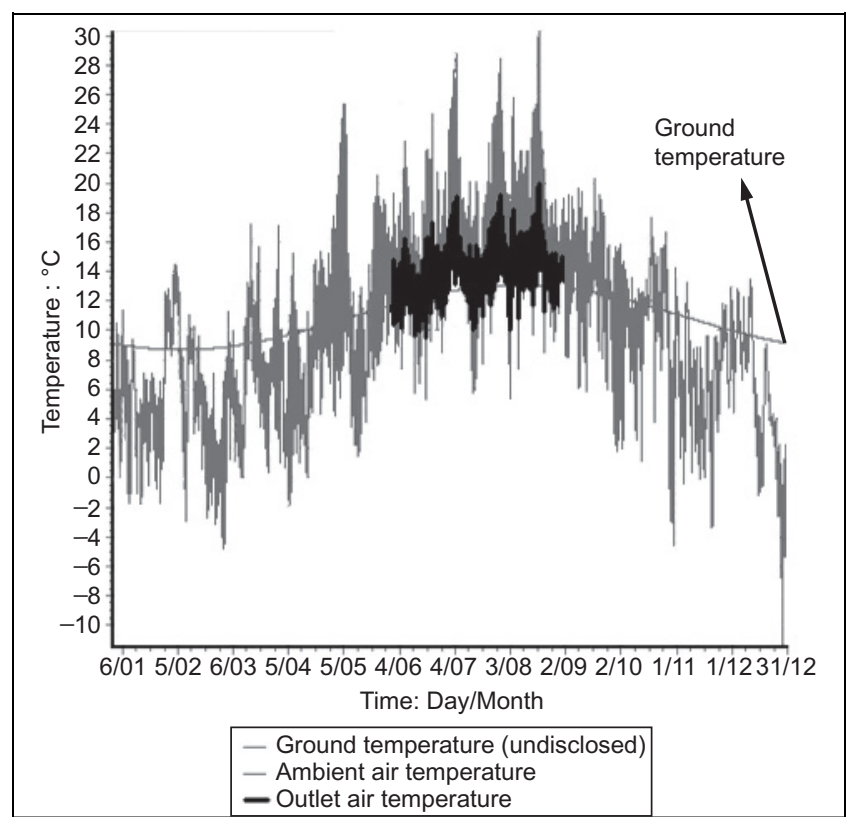

Figure II. Temperature curves showing summer expected operation of the BASF house Awadukt system

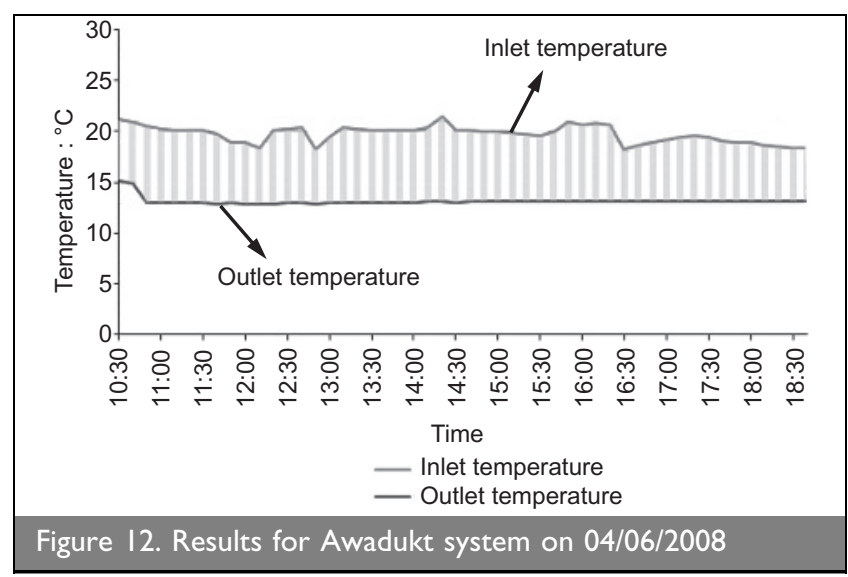

Figures 12 and 13. The low-energy fan was left on from 10:30am to 6:30pm on each day for a measured outlet speed of around $4.7 \mathrm{~m} / \mathrm{s}$ or $133 \mathrm{~m}^{3} / \mathrm{h}$ (slightly below the modelled air flow rate owing to the fan size used in the installation). The power required to run the fan at that speed is $18 \mathrm{~W}$.

Taking 5 June as an example, the system provided adequate levels of fresh air with an average cooling output during the $8 \mathrm{~h}$

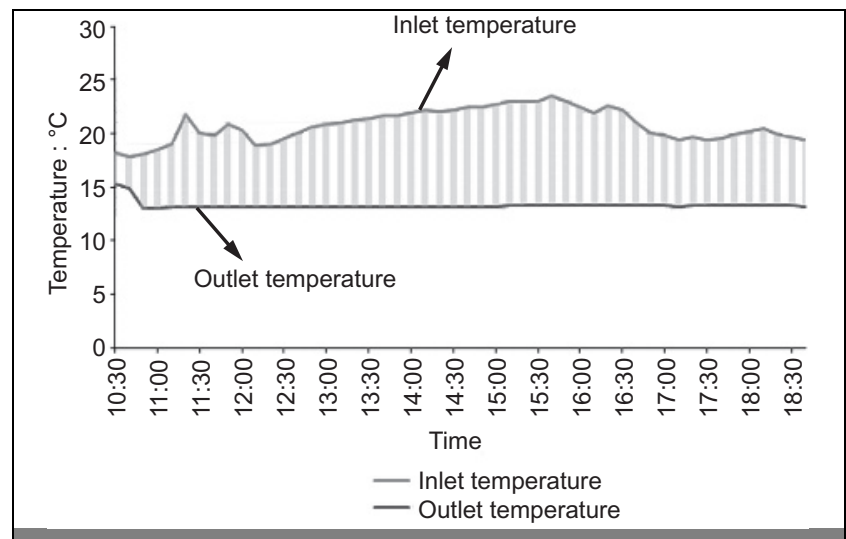

Figure 13. Results for Awadukt system on 05/06/2008 
period of $336 \mathrm{~W}(2 \cdot 7 \mathrm{KWh}$ cooling). The average inlet temperature during that period was $20 \cdot 8^{\circ} \mathrm{C}$ while the average outlet temperature was $13 \cdot 3^{\circ} \mathrm{C}$.

The results show that generally the outlet temperature is just above $13^{\circ} \mathrm{C}$ on all the monitored days. It also demonstrates that there is some heat saturation of the pipe-work and possibly the surrounding soil as the outlet temperature tends to increase by the end of the day but always by less than $1^{\circ} \mathrm{C}$.

For this short duration the Awadukt system appears to be working as predicted by the company's software. However, a direct comparison is difficult as the software modelled the system for the whole year. Ideally a full set of data for a year from the installed system would provide a better comparison between the software and actual data. The authors did not wish to prescribe to the occupants which systems they were to use while in the house. Long-term monitoring of the system will be carried out over the next few years when the system will potentially be used more.

\section{DISCUSSION AND CONCLUSIONS}

The UK Government has set ambitious targets for reducing the carbon dioxide emissions associated with energy use in buildings, including the target for all new homes to be zero carbon by 2016. Clearly these targets will require significant step changes in the design process and construction practice. It is therefore essential that the early low-carbon exemplar buildings are monitored (post-occupancy) to ensure that they perform in the manner they were designed to. This information is vital so that industry can learn about what works well in practice; that is what design measures actually deliver the predicted results. POE studies therefore have a key role in ensuring the zero-carbon targets are successfully met.

Previous work has suggested that airtight super-insulted lightweight buildings may suffer from summer overheating problems, a fact that will become increasingly important as UK temperatures rise owing to man-made climate change. It is therefore essential that robust solutions are found that may alleviate these problems while at the same time facilitating the successful use of lightweight off-site manufactured solutions for housing. In addition to good ventilation and solar shading strategies, this paper has outlined two other strategies that may be useful for preventing summer overheating: PCMs and EAHEs. These two technologies are being trialled as part of the Creative Energy Homes Project at the University of Nottingham. Although the monitoring phase of the project is still in its infancy, a sample set of initial monitoring results for the BASF House EAHE system show that the system is operating adequately as ambient air temperature fluctuation is well suppressed by the underground heat exchanger (i.e. heat is absorbed from or rejected to the ground) and the fresh supply air temperature is fairly constant around the soil temperature at a depth of $1.5 \mathrm{~m}$.

Since June 2008, the BASF house has been inhabited by three persons and their behaviour and the house performance have been closely monitored since April 2009. Overall the internal conditions have been described by users as comfortable on both warm and cold days. To date there has been little need to use the biomass heating system for space heating. Occupants have expressed contentment for being able to interact with the house and the outside environment directly by controlling openings and blinds rather than just relying on mechanical automated systems. This real-life experiment will provide vital data on the advantages and potential disadvantages of living in a lowenergy home designed to the current Code for Sustainable Homes level 4 standard. In order to ensure that the CEH perform as expected and provide high levels of user satisfaction, detailed work on the post-occupancy evaluation of all the homes constructed on Green Close will be carried out over the next few years. This work undertaken by the Department of the Built Environment at the University of Nottingham will be published at a later date.

\section{ACKNOWLEDGEMENTS}

The authors of this paper would like to thank the partners/ sponsors for their support of the Creative Energy Homes Project which has enabled the associated research programme - in particular BASF, Rehau, MicroWatt, E.on, Engineering and Physical Sciences Research Council (EPSRC) and WebBrick Systems whose support facilitated the work included in this paper. More information can be found at: www.creative-energyhomes.co.uk

\section{REFERENCES}

ARUP (2005) UK Housing and Climate Change, Heavyweight vs. Lightweight Construction. Arup Research and Development, Bill Dunster Architects, Feilden Clegg Bradley Architects, the RIBA. See http://www.greenspec.co.uk/documents/ whitepapers/Climate_Change_BDA_report.pdf for further details (accessed 01/06/2009).

BASF (2008) Building a Sustainable Future - the BASF House. BASF plc, Cheshire, UK. See www.house.basf.co.uk for further details (accessed 01/06/2009).

Bird J and Ross C (2002) Mechanical engineering Principles. Newnes, 0xford.

Brown G Prime Minister (2007) Speech on climate change, 19 November 2007. See http://www.number10.gov.uk/ pp. 13791 for further details (accessed 01/10/2009).

CIBSE (Chartered Institution of Building Services Engineers) (2005) Natural ventilation in non-domestic buildings. TCIoBS Engineers, London. CIBSE Publications. Applications manual AM10.

CLG (Communities and Local Government) (2008) Energy Performance of Buildings. See www.communities.gov.uk/ planningandbuilding/theenvironment/energyperformance/ for further details (accessed 01/10/2008).

CLG (Communities and Local Government) (2009) Code for Sustainable Homes. RIBA Publishing, London, UK.

Fjaerem A (2004) Coolhouse Final Monitoring Report Urbanizaçao das Furnas. Faber Maunsell, London, p. 29.

Kennett S (2005) Domestic bliss. Building Services Journal, May: $42-45$.

Littlefair P (2005) Avoiding air-conditioning. BRE-Constructing the Future 24:11.

Meulenaer VD, Veken JVd, Verbeeck G and Hens H (2005) Comparison of measurements and simulations of a passive house. Proceedings of 9th International IBPSA Conference Montreal, pp. 769-775.

Mother Earth News Editors (1986) Heating and cooling with the sun. Mother Earth News 63(100). 
Preiser WFE, Rabinowitz HZ and White ET (1988) Post-

Occupancy Evaluation. Van Nostrand Reinhold, New York.

Roaf S, Fuentes M and Thomas S (2003) Ecohouse 2: a design guide. Architectural Press, London.

Sawhney RL, Buddhi D and Thanu NM (1997) Parametric Prediction of Existing Earth Cooling Tube Installation- An Experimental Approach. Proceedings of The National Energy Convention, India, pp. 118-127.
Stern N (2006) The economics of climate change. The Stern Review. University Press, Cambridge.

Thiers S and Peuportier B (2008) Thermal and environmental assessment of a passive building equipped with an earth-toair heat exchanger in France. Solar Energy, in press.

Trombe A, Pettit M and Bourret B (1991) Air cooling by earth tube heat exchanger: experimental approach. Renewable Energy 1(5-6): 699-707.

\section{What do you think?}

To discuss this paper, please email up to 500 words to the editor at journals@ice.org.uk. Your contribution will be forwarded to the author(s) for a reply and, if considered appropriate by the editorial panel, will be published as discussion in a future issue of the journal.

Proceedings journals rely entirely on contributions sent in by civil engineering professionals, academics and students. Papers should be 2000-5000 words long (briefing papers should be 1000-2000 words long), with adequate illustrations and references. You can submit your paper online via www.icevirtuallibrary.com/content/journals, where you will also find detailed author guidelines. 